\title{
Clinical and analytical experience of the National Poison Control Centre with synthetic cannabinoids
}

\author{
Slavica Vučinić ${ }^{1}$, Vesna Kilibarda ${ }^{1}$, Snežana Đorđević ${ }^{1}$, Dragana Đorđević ${ }^{1}$, Nataša Perković- \\ Vukčević1, Gordana Vuković-Ercegović1 ${ }^{1}$, Biljana Antonijević2, Marijana Ćurčić2 \\ Evica Antonijević ${ }^{2}$, and Gordana Brajković ${ }^{1}$

\begin{abstract}
National Poison Control Centre, Military Medical Academy, Medical Faculty University of Defense ${ }^{l}$, University of Belgrade Faculty of Pharmacy, Department of Toxicology "Akademik Danilo Soldatovic'”, Belgrade, Serbia
\end{abstract}

[Received in January 2018; Similarity Check in January 2018; Accepted in May 2018]

\begin{abstract}
A rising number of patients are being treated for overdosing with new psychoactive substances (NPS) available at the illegal drug market in Serbia. The aim of this study was to report clinical and analytical experience of the National Poison Control Centre of Serbia (NPCC) with synthetic cannabinoids (SCs) and point to the NPS available at the illegal drug market in our country. From January 2013 to December 2016, 58 patients (aged between 14 and 25) were treated for the effects of synthetic cannabinoids at the NPCC. Tachycardia was established in 53, mydriasis in 31, somnolence, nausea, vomiting, and agitation in 16, dizziness in 10, disorientation in 9, dyspnoea and chest pain in 4 , and loss of consciousness, pallor, paraesthesia, muscle twitches, and short-term memory impairment in 2 patients. After receiving symptomatic and supportive treatment in the emergency ward, all patients had fully recovered within $8 \mathrm{~h}$ and were discharged shortly afterwards. Another part of the study was focused on the analysis of the products known under their local street names as "Biljni tamjan" (herbal incense), "Beli slez", and "Rainbow Special" and the analysis of urine sampled from the patients with gas chromatography - mass spectrometry and high performance liquid chromatography. The detected synthetic cannabinoids were AB-PINACA, JWH-018, JWH-122, JWH-210, 5F-AKB48, and MDMB-CHMICA in herbal products and AB-FUBINACA, AB-CHMINACA, and MDMB-CHMICA in the urine samples. Our findings have shown the great capacity of NPCC to I) monitor NPS abuse in Serbia, II) reliably detect SCs in illicit products and biological samples, and III) clinically manage the adverse effects in their users. Future commitments of the NPCC will include systematic collection of relevant data on SCs and their adverse effects, detection of changes in purity and composition of the controlled NPS-based products, and raising the public awareness of NPS to improve the effectiveness of the national Early Warning System.
\end{abstract}

KEY WORDS: chromatography; early warning system; herbal incense; new psychoactive substances; rainbow special; spectrometry

The term new psychoactive substances (NPS) refers to "any new narcotic or psychotropic drug that is not controlled by the UN Convention on Narcotic Drugs from 1961 or the Convention on Psychotropic Substances from 1971, but which may pose a public health threat similar to controlled psychoactive substances" (1). Seventeen years ago, only a handful of NPS were available on the market as "new, legal, and safe" alternatives to illegal drugs (2). At that time they were sold openly in head shops, on the street, or on the Internet under the guise of "air fresheners", "bath salts", "designer drugs", "herbal highs", "research chemicals", "plant feeders", or even "food supplements" (3-5). Soon after that, NPS saw dramatic expansion in the global drug market. By the end of 2016, their number increased to over 620 and is still growing, with one or two NPS appearing every week. Although they are not under international

Correspondence to: Professor Slavica Vučinić, MD, PhD, Head of the National Poison Control Centre, Military Medical Academy and Medical Faculty, University of Defence, Belgrade, Serbia

E-mail: slavicavucinic406@gmail.com control, NPS have become a global problem, and many countries have already issued permanent or temporary control measures. This heterogeneous group of psychoactive substances includes over 180 synthetic cannabinoids, 104 synthetic cathinones, phenethylamines, piperazines, tryptamines, arylcyclohexyamines and other substances that mimic the effects of their parallels from the controlled psychoactive substances (PAS) but with higher potency and duration of effects $(2,6)$.

Synthetic cannabinoids or synthetic cannabinoid receptor agonists (SCRAs), the largest, most frequently used and seized group of NPS, was developed a few decades ago from the research of the endocannabinoid system or from research for new analgesics. They appeared on the market in 2005 under the street name "Spice", "herbal smoking mixtures", or "air fresheners" that do not contain cannabis, but when smoked they cause similar effects. Since they first appeared in Europe, SCRAs became the largest group of NPS monitored by the European Monitoring Centre for Drugs and Drug Addiction (EMCDDA) and 
EUROPOL through the EU Early Warning System (EWS) operating through the Reitox network, which currently includes 28 EU member states, Norway, the European Commission, and the candidate countries $(7,8)$.

Whilst they are cannabinoid receptor type $1\left(\mathrm{CB}_{1}\right)$ agonists functionally similar to $\Delta$-9-tetrahydrocannabinol (THC), SCRAs produce more severe and longer lasting health effects due to 20 to 100 times higher potency. The mechanisms of their toxicity are not fully elucidated, yet it is possible that their physiological effects are not limited to $\mathrm{CB}$ receptors.

Since 2008, when the forensic services in Germany and Austria detected the first synthetic cannabinoid, JWH-018 in a "Spice" product, their number and chemical diversity has changed considerably (2-7). Most SCRAs are manufactured by chemical companies in China and India and shipped as bulk powders to Europe. Although the purity of bulk powders is seldom determined, reports from South Korea range between $75 \%$ and $90 \%$ (5). Due to the high potency of SCRAs, one $\mathrm{kg}$ of powder may be used to produce thousands of doses.

The bulk powder is then dissolved in acetone and methanol, sprayed onto a plant material (usually Damiana and Lamiaceae herbs), dried, and packed (5). The products analysed in this study usually contained herbs such as Mentha and Thymus, sprayed with a SCRA mixture (11, 12).

The number of users boomed as the media started to advertise NPS as "merely relaxing herbal blends". They were smoked or inhaled as "herbal incense" or "liquid incense" in cartridges for e-cigarettes. Recent police seizures reported that now they take the form of powder or tablet.

Chemical classification of synthetic cannabinoids includes classical cannabinoids (tetrahydrocannabinol, other chemical constituents of cannabis and their structurally related synthetic analogues, e.g. AM-411, HU-210, etc.); non-classical cannabinoids [cyclohexylphenols or 3-arylcyclohexanols (e.g. CP-55, CP-47,497)]; hybrid cannabinoids [combinations of classical and non-classical cannabinoids (e.g. AM-4030)]; aminoalkylindoles [naphtoylindoles (e.g. JWH-015, JWH-018, JWH-073, JWH-122, JWH-210), phenylacetylindoles (e.g. JWH-250, JWH-251), benzoylindoles (e.g. AM-694), naphtylmethylindoles (e.g. JWH-184), cyclopropoylindoles,

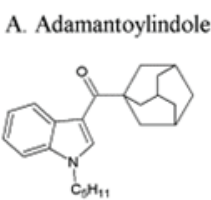

AB-001

D. Cyclohexylphenol

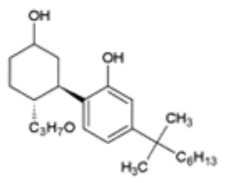

CP 55,940

G. Naphthoylindole

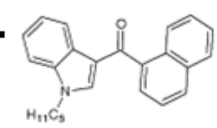

JWH-018

J. Naphthoylpyrrole

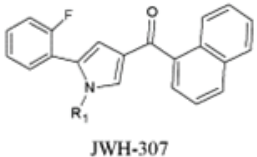

JWH-307
B. Aminoalkylindole

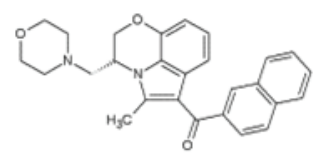

WIN $55,212-2$

E. Dibenzopyran

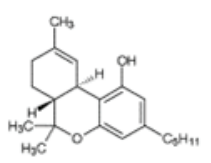

delta-9-THC

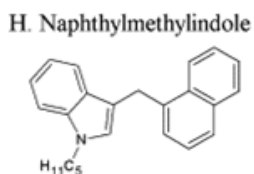

JWH-175

K. Phenylacetylindole

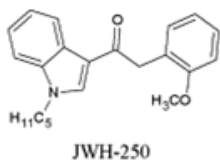

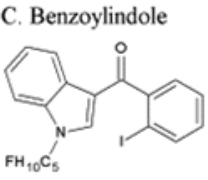

AM694

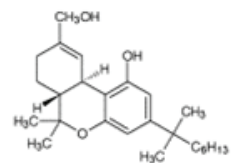

HU-210

F. Indazole carboxamide

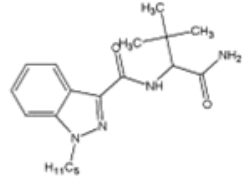

ADB-PINACA

I. Naphthylmethylindene

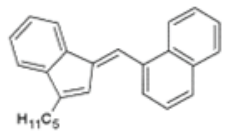

JWH-176

L. Quinolinyl ester indole

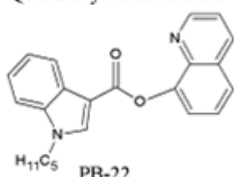

M. Tetramethylcyclopropyl ketone indole

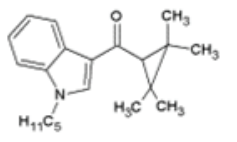

UR-144

Figure 1 Chemical structure of synthetic cannabinoids 
(e.g. UR-144, XRL-11), adamantoylindoles (e.g. AM1248), and indole carboxamides (e.g. STS-135)]; eicosanoids [anandamide (e.g. AM-356)]; and others [diarylpyrazoles, naphtoylpyrroles (e.g. JWH-307), naphthylmethylindenes (e.g. JWH-176), and indazole carboxamides (e.g. APINACA)] (11) (Figure 1).

However, their full pharmacological profiles are unavailable, and the clinical spectrum is therefore still not complete. Beside the effects on the central nervous system (agitation, confusion, hallucinations, tremor, convulsions, muscle spasms, paranoia, psychosis a.k.a. "spiceophrenia", somnolence, and suicidal thoughts and actions), they are associated with cardiovascular effects (tachycardia, hypertension, chest pain, and dyspnoea), nausea, vomiting, hypokalaemia, high creatine phosphokinase, and more recently with cerebrovascular infarction, acute renal failure, and acute myocardial infarction in previously healthy young people, including fatalities (5-13).

For example, MDMB-FUBINACA was responsible for more than 600 poisonings, including 15 fatalities in Russia (2). In 2015, hospitals in the United States reported a rise in the number of poisonings with ADB-FUBINACA requiring emergency treatment (2). EMCDDA issued public health alerts about MDMB-CHMICA in 2016, as poisonings and even fatalities were reported in several countries in Europe and the USA. In the first nine months of 2017, poison control centres in the USA reported 1837 poisonings, and called for real-time monitoring (14).
Prevalence data have shown notable differences between the European and US drug markets. Although the number of users is declining in Europe and US in general, there are specific groups (clubbers, internet users, etc.) who use SCRAs more than others (5). According to the 2012 Global Drug Survey, the prevalence in the UK among all respondents was $3.3 \%$ and among regular clubbers $5 \%(2$, $5,6)$.

The Early Warning System in Serbia is active since 2016, with the National Poison Control Centre (NPCC) as one of its key subjects (Figure 2) responsible for the diagnosis and treatment of poisoning, defining the clinical picture related to NPS, risk assessment, and reporting to the National Monitoring Centre for Drugs and Drug Addiction in Serbia. This EWS is to report to the EU EWS annually or according to the risk assessment (15).

The aim of our study was to report clinical and analytical experience of the NPCC with synthetic cannabinoids and point to the new psychoactive substances (NPS) available at the illegal drug market in our country.

\section{PATIENTS AND METHODS}

Our study spanned from January 2013 to December 2016 and included 58 patients aged between 14 and 25 years ( 5 in 2013, 14 in 2014, 36 in 2015, and 3 in 2016) who were treated for the effects of SCRAs at the Department of

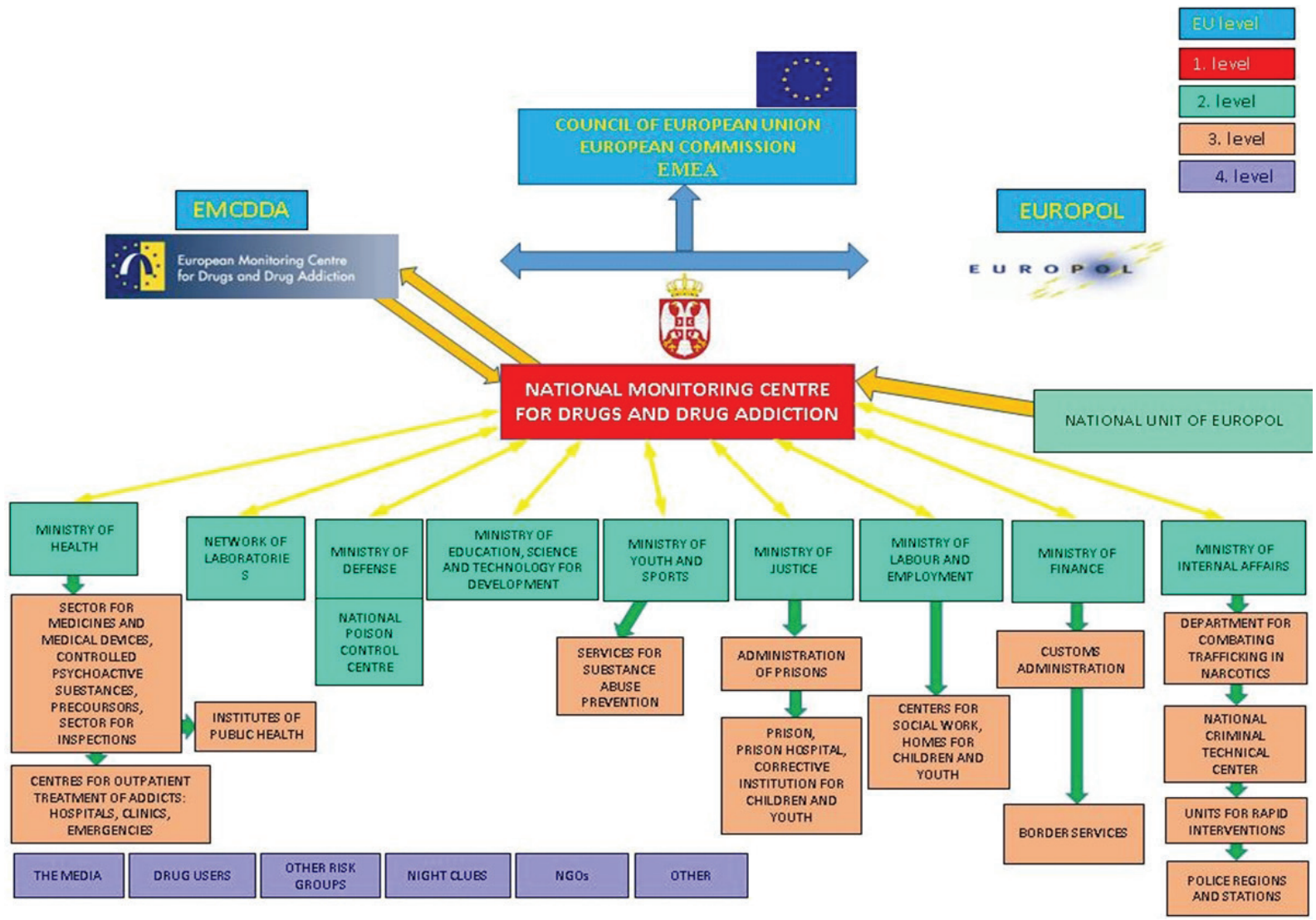

Figure 2 Organisational structure of partners in the Early Warning System of Serbia 
Reanimation and Triage (DRT) of the National Poison Control Centre (NPCC) in Belgrade, Serbia. All of them reported the use of "synthetic cannabinoids" or "herbal incense", sometimes under the brand or street names "Biljni tamjan", "Beli slez", "Rainbow Special", "Bad-Mad", "Sharp Blueberry", "Sharp-Aroma", "Galaxy", "Black Grass", and "Luminated", which they obtained from friends, in tobacco shops, or online as natural herbal products and air fresheners and consumed them by smoking or inhaling the smoke. We took their medical history, examined them, and administered symptomatic and supportive treatment.

We also took 10 samples of herbal material and 10 urine samples from patients who agreed to do it. Herbal samples were macerated in $1 \mathrm{~mL}$ of methanol, and $1 \mu \mathrm{L}$ of the methanol solution was injected into the instrument. The compound of interest was separated from the matrix on a DB5 column (30 m x $0.25 \mathrm{~mm}$ I.D. $0.25 \mu \mathrm{m}$ thickness, Thermo Scientific, Waltham, Massachusetts, USA). The column temperature was initially set at $80{ }^{\circ} \mathrm{C}$ and held isothermal for $2 \mathrm{~min}$ after injection, then ramped to $260^{\circ} \mathrm{C}$ at a rate of $20^{\circ} \mathrm{C} \mathrm{min}^{-1}$ and held isothermal for $10 \mathrm{~min}$, then again ramped to $300{ }^{\circ} \mathrm{C}$ at a rate of $5{ }^{\circ} \mathrm{C} \mathrm{min}-1$ and kept there for $5 \mathrm{~min}$. The injector temperature was $260^{\circ} \mathrm{C}$, with split gas flow of $50 \mathrm{~mL} \mathrm{~min}{ }^{-1}$. Carrier gas flow was $1 \mathrm{~mL} \mathrm{~min}{ }^{-1}$. The temperatures of the transfer line and ion source were $200{ }^{\circ} \mathrm{C}$ and $260{ }^{\circ} \mathrm{C}$, respectively. Mass ions were detected in the full scan range of 50-600 m/z. SCARs were identified by matching the readings against the US National Institute of Standards and Technology (NIST) library.

Urine was used to identify SCRAs of indole structure, such us AB-CHMINACA and its carboxy metabolite. First, we ran alkaline hydrolysis by adding of $1 \mathrm{~mL}$ of $10 \mathrm{~mol} \mathrm{~L}^{-1}$ sodium hydroxide to $10 \mathrm{~mL}$ of urine and heating the mix to $55^{\circ} \mathrm{C}$ in a water bath for $30 \mathrm{~min}$. After the hydrolysis and $\mathrm{pH}$ adjustment to 4 with $1 \mathrm{~mol} \mathrm{~L}^{-1}$ hydrochloric acid, SCRA metabolites were extracted with diethyl ether. The organic layer was evaporated, and dried extracts reconstituted in $1 \mathrm{~mL}$ of methanol. For SCRAs with indasole structure, neutral solid phase extraction was done before analysis. After activation of the cartridge with methanol and water, $1 \mathrm{~mL}$ of urine sample was loaded. The cartridge was washed with $1 \mathrm{~mL}$ of $5 \%$ methanol, and SCRAs were eluted with $1 \mathrm{~mL}$ of methanol. The extracts were analysed with a Waters high performance liquid chromatographer / mass spectrometer (HPLC-ESI-MS) or a Waters 2695 HPLC coupled with Waters photodiode array (PDA) 2696 detector (Waters, Milford, MA, USA). The mobile phase for HPLC/ PDA was a mixture of phosphate buffer $(\mathrm{pH} 3.6)$ and acetonitrile. SCRA metabolites were separated from the matrix on a Symmetry C8 column $(5 \mu \mathrm{m}, 4.6$ x $250 \mathrm{~mm}$, Waters) in gradient mode (Table 1).

The SCRAs were identified by their UV spectrum and confirmed with a Waters 2695 HPLC coupled with Waters ZQ mass spectrometric detector with electrospray ionisation. The compounds of interest were separated on a
Table 1 Composition of mobile phase for HPLC/PDA

\begin{tabular}{ccccc}
\hline $\begin{array}{c}\text { Time } \\
\text { (min) }\end{array}$ & $\begin{array}{c}\text { Flow } \\
(\mathbf{m L} \\
\left.\text { min }^{-1}\right)\end{array}$ & $\begin{array}{c}\text { \% A } \\
\text { (phosphate } \\
\text { buffer) }\end{array}$ & $\begin{array}{c}\text { \% B (aceto- } \\
\text { nytrile) }\end{array}$ & Curve \\
\hline initial & 1.0 & 85 & 15 & - \\
\hline 3 & 1.0 & 85 & 15 & 6 \\
\hline 9 & 1.0 & 65 & 35 & 6 \\
\hline 28 & 1.5 & 20 & 80 & 6 \\
\hline 30 & 1.0 & 85 & 15 & 6 \\
\hline
\end{tabular}

Table 2 Composition of mobile phase for LC/MS

\begin{tabular}{ccccc}
\hline $\begin{array}{c}\text { Time } \\
\text { (min) }\end{array}$ & $\begin{array}{c}\text { \%A } \\
\text { (formiate } \\
\text { buffer) }\end{array}$ & $\begin{array}{c}\% \text { B } \\
\text { (acetonytrile) }\end{array}$ & $\begin{array}{c}\text { Flow } \\
(\mathbf{m L} \\
\left.\mathbf{m i n}^{-1}\right)\end{array}$ & Curve \\
\hline initial & 95 & 5 & 0.1 & 1 \\
\hline 2 & 95 & 5 & 0.2 & 6 \\
\hline 16 & 10 & 90 & 0.2 & 6 \\
\hline 20 & 95 & 5 & 0.2 & 5 \\
\hline 26 & 95 & 5 & 0.2 & 5 \\
\hline
\end{tabular}

Waters XTerra C18 column (3.5 $\mu \mathrm{m}, 4.6 \times 150 \mathrm{~mm})$, which was heated to $30^{\circ} \mathrm{C}$. The analytical conditions for the MS detector were: capillary voltage $3 \mathrm{kV}$, ion source temperature $125{ }^{\circ} \mathrm{C}$, desolvation temperature $430{ }^{\circ} \mathrm{C}$, desolvation nitrogen flow $400 \mathrm{~L} \mathrm{~h}^{-1}$, and nitrogen flow on the cone $50 \mathrm{~L} \mathrm{~h}^{-1}$. The mobile phase was a mixture of $5 \mathrm{mmol} \mathrm{L}^{-1}$ of ammonium formiate ( $\mathrm{pH} 3.5)(\mathrm{A})$ and acetonitrile (B) in gradient mode (Table 2).

SCRAs and metabolites were identified by their characteristic ions. The principal ions for confirmation were as follows: AB-CHMINACA $m / z$ 357, 241, 312, 144; ABCHMINACA carboxy metabolite $m / z$ 358, 241, 312, 144 (at the cone voltage of $50 \mathrm{~V}$ ).

\section{RESULTS}

Table 3 shows the signs and symptoms of SCRA overdose in the order of their frequency. The most frequent signs were tachycardia, mydriasis, and somnolence, while the least common symptoms were loss of consciousness, pallor, paraesthesia, muscle twitches, and short-term memory impairment.

In the tested herbal product "Biljni tamjan" (herbal incense) GC-MS identified JWH-122 (Figure 3), and JWH210 (Figure 4). 5F-AKB48 was found in the herbal product "Galaxy" (Figure 5) and AB-PINACA (Figure 6) in the herbal product "Bad-Mad". MDMB-CHMICA was detected in a cigarette (Figure 7).

Urine HPLC-ESI-MS detected the carboxy metabolites of AB-FUBINACA (in three patients), AB-CHMINACA (in six patients), and MDMB-CHMICA (in one patient).

To illustrate signs and symptoms of SCRAs overdose witnessed at the DRT NPCC we present two typical cases below. After receiving symptomatic treatment, all patients 
Table 3 Adverse effects of SCRA overdose in 58 patients treated at the NPCC from 2013 to 2016

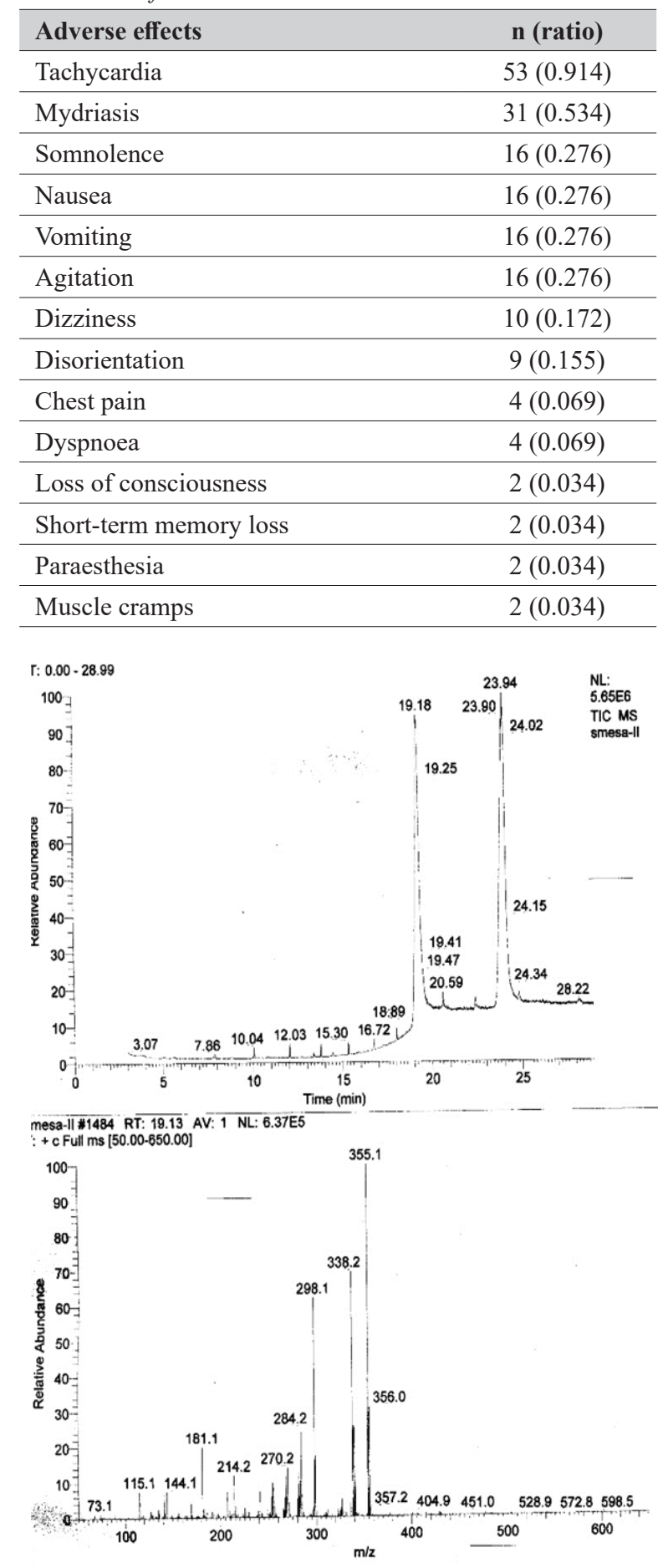

Figure 3 GC/MS chromatogram and mass spectrum of JWH-122 ("Biljni tamjan" / herbal incense)

had fully recovered within $8 \mathrm{~h}$ and were discharged shortly afterwards.

\section{Case report 1}

A 22-year-old woman was admitted to the DRT NPCC after having smoked the herbal product known under local name "Biljni tamjan" (herbal incense) bought in a head

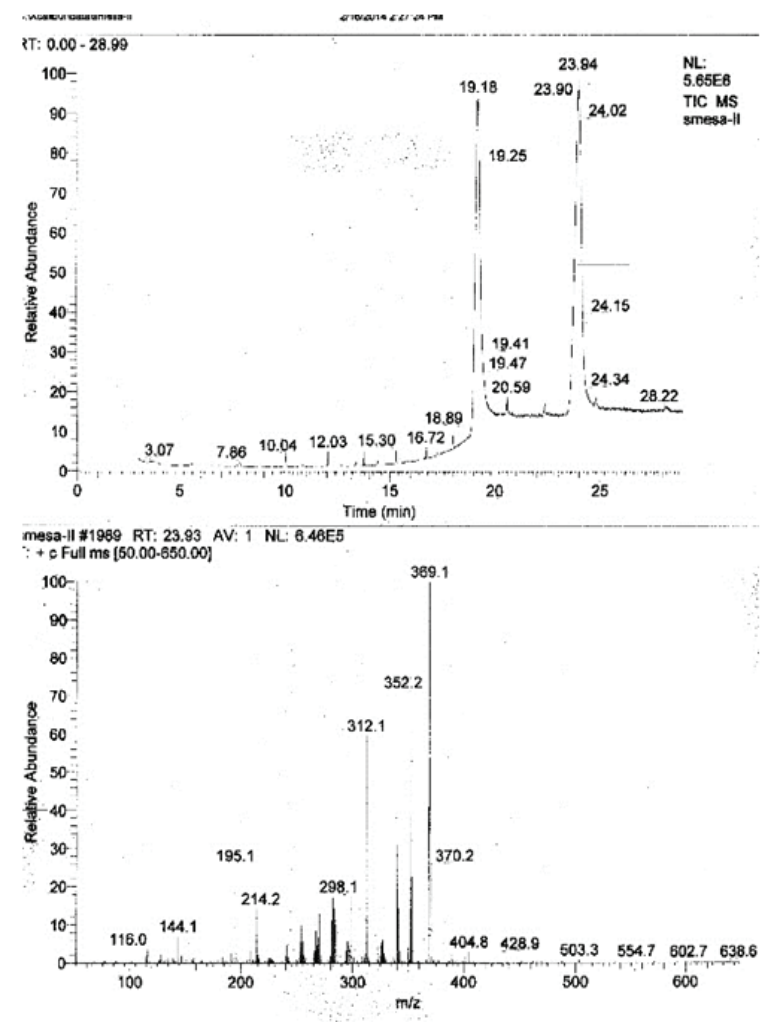

Figure 4 GC/MS chromatogram and mass spectrum of JWH-210 ("Biljni tamjan" / herbal incense)

shop. Some 20 minutes after smoking, she was trembling and had palpitations, chest pain, and vertigo. On the admission she was conscious, oriented, with moderate agitation and mydriasis. Her vital signs were as follows: blood pressure 160/90 $\mathrm{mmHg}$, pulse $168 \mathrm{~min}^{-1}$, respiratory rate $13 \mathrm{~min}^{-1}$, and blood oxygen saturation $98 \%$. ECG showed sinus rhythm with the heart rate of $112 \mathrm{~min}^{-1}$ without other changes. GC/MS detected JWH-122 in the herbal product (Figure 2). She received $500 \mathrm{~mL}$ of a $5 \%$ intravenous glucose infusion and $10 \mathrm{mg}$ of intramuscular diazepam. She fully recovered within four hours and was discharged after the adverse effects of SCRAs withdrew.

\section{Case report 2}

A 23-year-old man was admitted to the DRT NPCC after having smoked the herbal product "Rainbow", also bought in a head shop. He explained that he wanted to "try something new and lift his mood". Soon after using it, he was found in the attic of his house highly agitated, yelling, disoriented, with visual hallucinations. On the admission he was conscious, disoriented, with agitation and mydriasis. His vital signs were as follows: blood pressure $125 / 75 \mathrm{mmHg}$, heart rate $138 \mathrm{~min}^{-1}$, respiratory rate $14 \mathrm{~min}^{-1}$, blood oxygen saturation $96 \%$. ECG showed sinus rhythm with the heart rate of $110 \mathrm{~min}^{-1}$ without other changes. Urine HPLC-ESIMS detected the AB-FUBINACA carboxy metabolite. The patient received $500 \mathrm{~mL}$ of Hartmann's solution (i.v.) and $10 \mathrm{mg}$ of intramuscular diazepam. He recovered fully within 


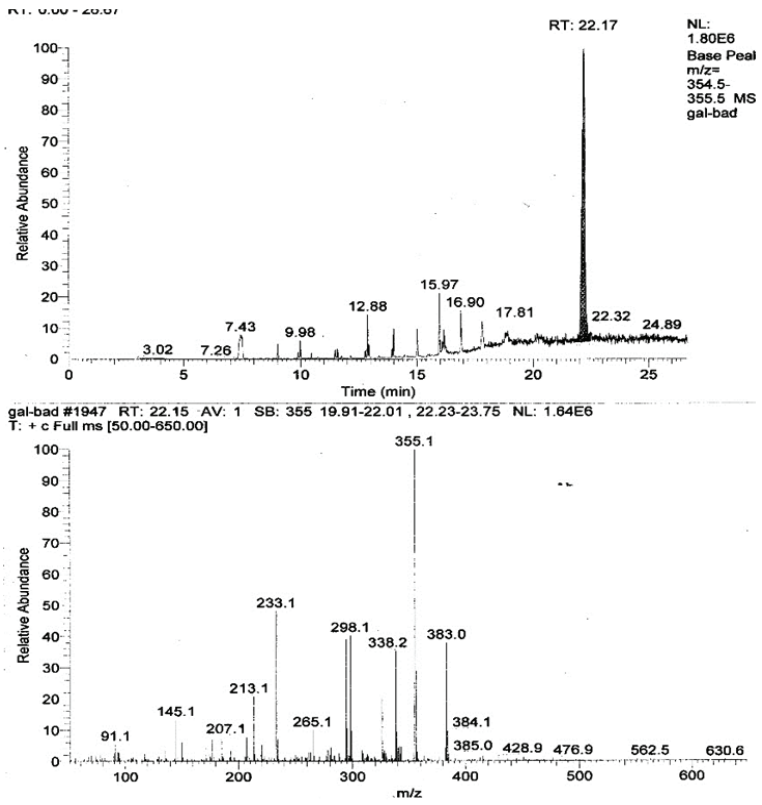

Figure 5 GC/MS chromatogram and mass spectrum of $5 F-A K B$ ("Galaxy")

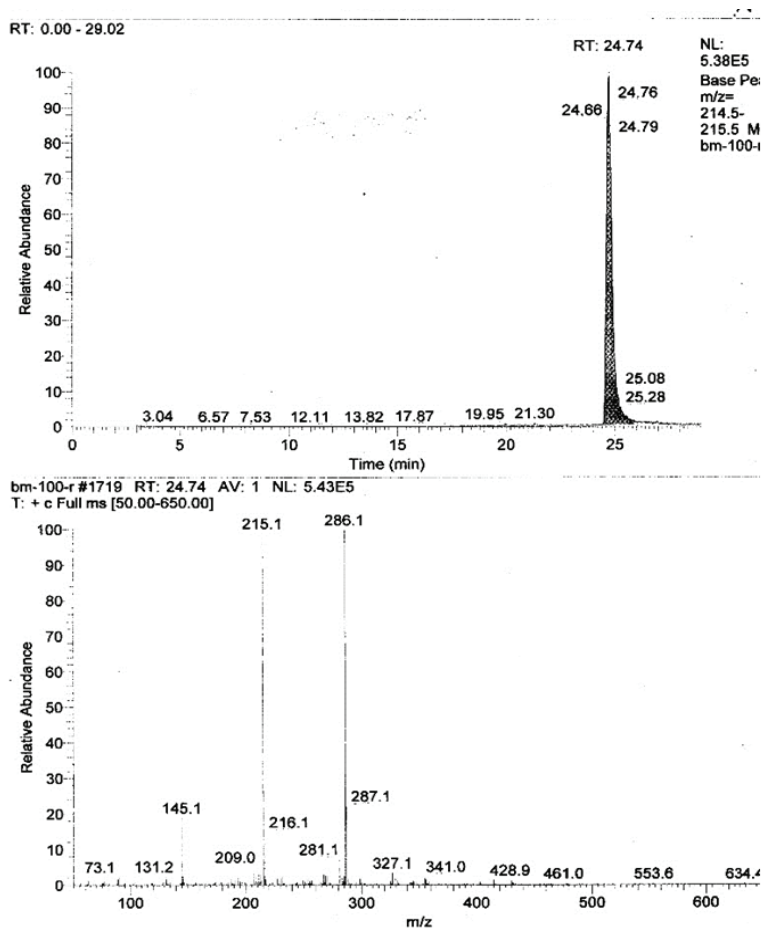

Figure $6 G C / M S$ chromatogram and mass spectrum of $A B$ PINACA ("Bad-Mad")

five hours and was discharged after the adverse effects of SCRAs withdrew.

\section{DISCUSSION}

Susceptibility to the effects of SCRAs is individual and depends on the intrinsic properties of these substances, their concentration in the product, the mode and frequency of use, and several other predisposing factors and comorbidities.
The findings and the symptoms observed among our patients were in line with the most common adverse effects reported in the literature, including agitation, nausea, and tachycardia. Less common adverse effects include heart attack, seizures, rhabdomyolysis with kidney damage, and psychosis $(3,5,7,8,10)$, but they were not observed among our patients.

The growing number of SCRAs on the global and national market, their chemical diversity, frequent changes in composition, and difficulties that come with the analysis of these substances pose a significant challenge for clinical toxicologists and forensic services. Routine analysis and screening of these substances in biological samples and seized materials mainly rely on the analytical methods such as $\mathrm{GC} / \mathrm{MS}, \mathrm{HPLC} / \mathrm{MS}$, and immunochemical assays (10, 16-23).

What often makes the work of forensic and clinical services difficult are technical limitations or unwillingness of some patients to consent to the analysis. Because of that, it is not always possible to detect the specific substance in biological samples.

Even so, our findings have confirmed the capability of the NPCC to monitor NPS abuse in Serbia, detect them in illicit products and biological samples, and clinically manage adverse effects in their users.

The NPCC has committed itself to efficiently and systematically collect relevant data on synthetic cannabinoids and their adverse effects in the future, to monitor changes in the purity and composition of controlled PS and NPS-based products, and raise the public awareness of the NPS so as to improve the effectiveness of the national EWS.

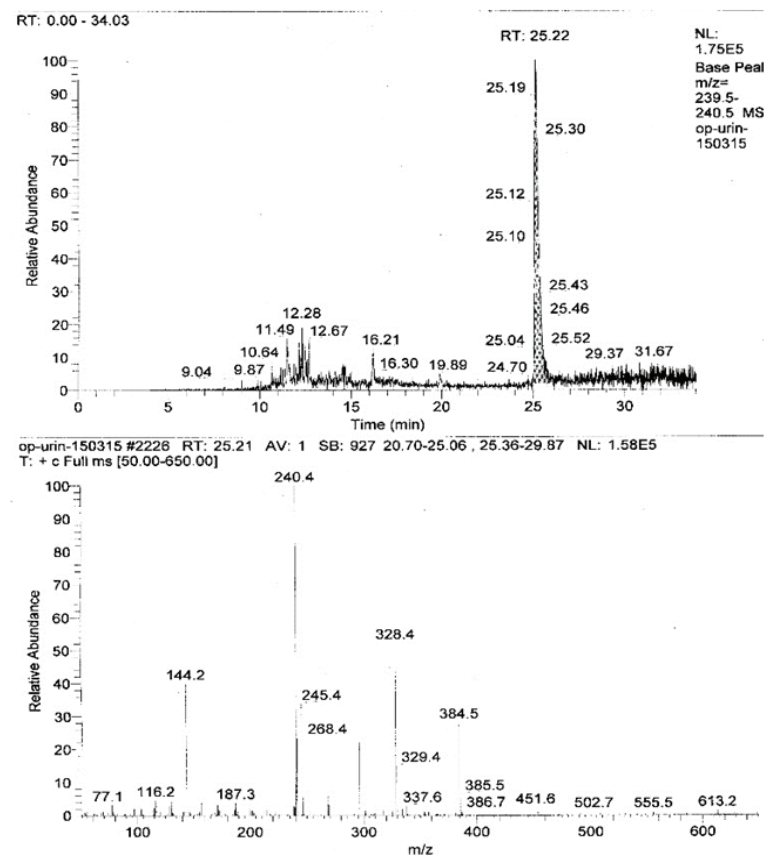

Figure 7 GC/MS chromatogram and mass spectrum of MDMBCHMICA (in a cigarette) 
Clinical and analytical experience of the NPCC, development and fine-tuning of the existing and the implementation of new detection methods, and the exchange of information with other key stakeholders nationwide and internationally through the EWS in Serbia and EU will help to adequately monitor SCRA trends and promptly issue necessary legislative measures.

\section{Ethical approval}

According to the Medicines and Medical Devices Agency of Serbia, retrospective research involving human subjects or a patient file research does require the ethical approval by the institutional review board (in this case the Ethics Committee of the Military Medical Academy).

This research has been performed in accordance with the ethical standards laid down in the 1964 Declaration of Helsinki and its later amendments.

\section{Informed consent}

For this type of study formal informed consent is not required.

\section{REFERENCES}

1. Council Decision $2005 / 387 /$ JHA of 10 May 2005 on the information exchange, risk-assessment and control of new psychoactive substances [displayed 10 May 2018]. Available at https://publications.europa.eu/en/publication-detail/-/ publication/1220f240-3fla-4a14-9df7-9cd2b297f4bb/languageen

2. European Monitoring Centre for Drugs and Drug Addiction (EMCDDA). Understanding the 'Spice' Phenomenon. Thematic papers. Lisbon: EMCDDA; 2009.

3. Gurney SM, Scott KS, Kacinko SL, Presley BC, Logan BK. Pharmacology, toxicology, and adverse effects of synthetic cannabinoid drugs. Forensic Sci Rev 2014;26:53-78. PMID: 26226970

4. Hurst D, Loeffler G, McLay R. Psychosis associated with synthetic cannabinoid agonists: a case series. AmJ Psychiatry 2011;168:1119. doi: 10.1176/appi.ajp.2011.11010176

5. European Monitoring Centre for Drugs and Drug Addiction (EMCDDA). Perspectives on Drugs. Synthetic cannabinoids in Europe [displayed 4 May 2018]. Available at http://www.emcdda. europa.eu/system/files/publications/2753/POD_Synthetic\%20 cannabinoids_0.pdf

6. European Monitoring Centre for Drugs and Drug Addiction (EMCDDA). Synthetic cannabinoids and "Spice" drug profile [displayed 4 May 2018]. Available at https://www.emcdda.europa. eu/publications/drug-profiles/synthetic-cannabinoids

7. Namera A, Kawamura M, Nakamoto A, Saito T, Nagao M. Comprehensive review of the detection methods for synthetic cannabinoids and cathinones. Forensic Toxicol 2015;33:175-94. doi: 10.1007/s11419-015-0270-0

8. Lapoint J, James LP, Moran CL, Nelson LS, Hoffman RS, Moran $\mathrm{JH}$. Severe toxicity following synthetic cannabinoid ingestion. Clin Toxicol 2011;49:760-4. doi: 10.3109/15563650.2011.609822
9. Spaderna M,Addy PH, Deepak CDS. Spicing things up: Synthetic cannabinoids. Psychopharmacology (Berl) 2013;228:525-40. doi: 10.1007/s00213-013-3188-4

10. Brents LK, Reichard EE, Zimmerman SM, Moran JH, Fantegrossi WE, Prather PL. Phase I hydroxylated metabolites of the K2 synthetic cannabinoid JWH-18 retain in vitro and in vivo cannabinoid 1 receptor affinity and activity. PLoS One 2011;6(7):e21917. doi: 10.1371/journal.pone.0021917

11. Ergül DF, Ekemen S, Yelken BB. Synthetic cannabinoid 'Bonsai' intoxication: six case series. Turk J Anaestesiol Reanim 2015;43:347-51. doi: 10.5152/TJAR.2015.05668

12. United Nations Office on Drugs and Crime (UNODC). Synthetic cannabinoids in herbal products, 2011 [displayed 4 May 2018]. Available athttps://www.unodc.org/unodc/en/scientists/syntheticcannabinoids-in-herbal-products_new.html

13. Papanti D, Schifano F, Botteon G, Bertossi F, Mannix J, Vidoni D, Impagnatiello M, Pascolo-Fabrici E, Bonavigo T. "Spiceophrenia": a systematic overview of "Spice"-related psychopathological issues and a casereport. Hum Psychopharmacol Clin Exp 2013;28:379-89. doi: 10.1002/hup.2312

14. American Association of Poison Control Centres. Synthetic Cannabinoids [displayed 4 May 2018]. Available at http://www. aapcc.org/alerts/synthetic-cannabinoids/

15. European Monitoring Centre for Drugs and Drug Addiction (EMCDDA). Health responses to new psychoactive substances. Lisbon: EMCDDA; 2016. doi: 10.2810/042412

16. European Monitoring Centre for Drugs and Drug Addiction (EMCDDA). New psychoactive substances in Europe. An update from the EU Early Warning Sytem March 2015. Luxembourg: Publication Office of the European Union; 2015. doi: $10.2810 / 372415$

17. Emerson B, Durham B, Gidden J, Lay Jr JO. Gas chromatographymass spectrometry of JWH-018 metabolites in urine samples with direct comparison to analytical standards. Forensic Sci Int 2013;229:1-6. doi: 10.1016/j.forsciint.2013.03.006

18. Moran CL, Le VH, Chimalakonda KC, Smedley AL, Lackey FD, Owen SN, Kennedy PD, Endres GW, Ciske FL, Kramer JB, Kornilov AM, Bratton LD, Dobrowolski PJ, Wessinger WD, Fantegrossi WE, Prather PP, James LP, Radominska-Pandya A, Moran JH. Quantitative measurement of JWH-018 and JWH-073 metabolites excreted in human urine. Anal Chem 2011;83:422836. doi: $10.1021 / \mathrm{ac} 2005636$

19. Hutter M, Broecker S, Kneisel S, Auwärter V. Identification of the major urinary metabolites in man of seven synthetic cannabinoids of the aminoalkylindole type present as adulterans in "herbal mixtures" using LC-MS/MS techniques. J Mass Spectrom 2012;47:54-6. doi: 10.1002/jms.2026

20. Schneir AB, Baumbacher T. Convulsions associated with the use of a synthetic cannabinoid product. J Med Toxicol 2012;8:62-4. doi: 10.1007/s13181-011-0182-2

21. Kronstrand R, Roman M,Andersson M, Eklund A. Toxicological findings of synthetic cannabinoids in recreational users. J Anal Toxicol 2013;37:534-41. doi: 10.1093/jat/bkt068

22. Mdege ND, Meader N, Lloyd C, Parrott S, McCambridge J. The Novel Psychoactive Sunstances in the UK Project: empirical and conceptual review of work to produce research recommendations. Final Report. Public Health Res 2017;5:1-11. doi: 10.3310/ phr05040

23. Busquets Garcia A, Soria-Gomez E, Bellochio L, Marsicano G. Cannabinoid receptor type-1: breaking the dogmas. F1000Res 2016;5. pii: F1000 Faculty Rev-990. doi: 10.12688/ f1000research.8245.1 
Klinička i analitička iskustva Nacionalnog centra za kontrolu trovanja sa sintetičkim kanabinoidima

U porastu je broj pacijenata koji se zbrinjava zbog predoziranja novim psihoaktivnim supstancijama (NPS), dostupnima na ilegalnom tržištu droga u Srbiji. Cilj je ovog rada prikazati klinička i analitička iskustva Nacionalnog centra za kontrolu trovanja (NCKT) sa sintetičkim kanabinoidima (SC) i upozoriti na NPS-ove dostupne na ilegalnom tržištu droga u Srbiji. Od siječnja 2013. do prosinca 2016. u NCKT-u je zbog učinaka sintetičkih kanabinoida zbrinuto 58 pacijenata u dobi od 14 do 25 godina. Njihova je klinička slika uključivala: tahikardiju (53 od 58 pacijenata), midrijazu (31), pospanost, mučninu, povraćanje i agitaciju (16), nesvjesticu (10), dezorijentaciju (9), dispneju i bol u prsima (4) te gubitak svijesti, bljedilo, parestezije, grčeve u mišićima i kratkotrajni gubitak pamćenja (2). Nakon odgovarajuće simptomatske i suportivne terapije u hitnoj službi, svi su se pacijenti potpuno oporavili u roku od osam sati i ubrzo nakon toga otpušteni. Drugi dio rada fokusiran je na analizu preparata poznatih pod nazivima "Biljni tamjan", "Bijeli sljez", "Rainbow Special", "Herbal incense" itd., i na analizu uzorka urina pacijenata metodom plinske kromatografije s masenom spektrometrijom i tekućinske kromatografije visoke djelotvornosti s masenom spektrometrijom. Detektirani su sljedeći sintetički kanabinoidi: ABPINACA, JWH-018, JWH-122, JWH-210, 5F-AKB48 i MDMB-CHMICA u biljnim proizvodima i AB-FUBINACA, AB-CHMINACA i MDMB-CHMICA u uzorcima urina. Rezultati tih analiza pokazali su da NCKT ima veliki kapacitet za I) praćenje zloporabe NPS-a u Srbiji, II) njihovu učinkovitu detekciju u biljnim proizvodima i biološkim uzorcima i III) kliničko liječenje toksičnih učinaka u korisnika tih supstancija. Kako bi pridonio učinkovitosti nacionalnog sustava ranog upozoravanja, NCKT će u budućnosti sustavno prikupljati relevantne podatke o sintetičkim kanabinoidima i njihovim štetnim učincima, detektirati promjenu čistoće i sastava kontroliranih psihoaktivnih supstancija i preparata na bazi NPSova, istodobno podižući svijest javnosti o tim supstancijama.

KLJUČNE RIJEČI: “biljni tamjan”; kromatografija; novi psihoaktivni spojevi; spektrometrija; sustav ranog upozoravanja 